\title{
The Relationship between Brand Experience, Customer Satisfaction and Customer Loyalty: Brand Trust as The Intervening Variable
}

\author{
Rahmi Yuliyasti ${ }^{1}$, Erni Masdupi ${ }^{2}$, Abror Abror ${ }^{3}$ \\ ${ }^{1}$ Faculty of Economics, Universitas Negeri Padang, Padang, Indonesia \\ $\square$ (e-mail) rahmiyuliyasti21@gmail.com \\ 2Department of Management, Faculty of Economics, Universitas Negeri Padang, Padang, Indonesia \\ $\bowtie$ (e-mail) emasdupi@gmail.com \\ ${ }^{3}$ Department of Management, Faculty of Economics, Universitas Negeri Padang, Padang, Indonesia \\ $\bowtie$ (e-mail) abror094@gmail.com, abror094@fe.unp.ac.id
}

\begin{abstract}
This study examines the influence of brand experiende and customer satisfaction on customer loyalty through brand trust as an intervening variable. This study was conducted to 166 customers of PT Bank Rakyat Indonesia (Persero) Tbk as the samples. We employed Structural Equation Modeling (SEM) by using AMOS 24 as the data analysis software package. The results showed that brand experience and customer satisfaction have a positive and significant effect on brand trust. Brand trust and brand experience have a positive and significant effect on customer loyalty. However, the result found that brand experience has no significant direct effect on customer satisfaction. Customer satisfaction also has insignificant impact on customer loyalty. Furthermore, some limitations and future study are discussed
\end{abstract}

Keywords: brand experience, customer satisfaction, and brand trust

\section{Introduction}

Bank Rakyat Indonesia (BRI) branch Padang Panjang has several segments of loans, which are grouped into commercial retail credit, micro credit (program and nonprogram), consumer loans (KPR, KKB and Briguna) and medium credit. In this study, the authors conducted a study especially on commercial retail credit which is currently being developed by BRI in addition to its core business known as the largest microcredit lending bank in Indonesia and has not been rivaled by other banks to date. The focus of research is the commercial retail credit. This business segment is growing rapidly recently which is in line with the current business market demand. The demands of microcredit need and the requested higher credit facilities are growing rapidly and they need to be extended to commercial retail credit facilities which is proof of success and increase their business.

Table 1 Growth distribution of credit by PT BRI (Persero) Tbk branch Padang Panjang years 2014 to 2016

\begin{tabular}{ccc}
\hline \multirow{2}{*}{ Years } & \multicolumn{2}{c}{ Nominal (IDR) } \\
\cline { 2 - 3 } & Total & Growth (\%) \\
\hline 2014 & $490,410.000,000,000$ & 13.80 \\
\hline 2015 & $558,400,000,000,000$ & 13.90 \\
\hline 2016 & $635,300,000,000,000$ & 13.80 \\
\hline
\end{tabular}

Bank BRI's evidence began to focus on commercial retail lending where BRI banks raised restrictions on commercial retail credit where previously commercial retail credit facilities were provided at BRI banks to customers with individual businesses and business entities ranging from credit plafond IDR100,000,000 to IDR5,000,000,000 and the year 2017 made an increase where the plafond lending starts from IDR100,000,000 up to IDR 15,000,000,000. This increase in the distribution of credit ceiling is one proof of the seriousness of BRI banks to manage the current commercial retail credit. The use of this commercial retail credit facility can be for working capital or investment to 
finance the objects that support the customer's business. Bank BRI's national credit growth from 2014 to 2016 is not so fluctuating as can be seen from Table 1.

The Table 1 shows that the growth of credit disbursement for all segments (Commercial Retail, Medium, corporation, micro, Consumer) for the last 3 years where the year 2014 grew 13.8\% with total disbursement of IDR490.41 trillion, in 2015 grew 13.9\% with total disbursement of IDR558.4 trillion, in 2016 grew 13.8\% with total distribution of IDR635.3 trillion. Based on the above loan figures, it appeared that the overall credit growth from year to year did not show significant growth.

Issues for commercial retail credit with fluctuating customer growth and nominal Commercial Bank Commercial Loan BRI branch Padang Panjang caused from unstable or inconsistent customer loyalty to BRI branch Padang Panjang where this condition suspected by factors such as the influence of experience, customer satisfaction and trust that can make its customers loyal to the banking facilities offered, especially Commercial Loans in branch BRI Padang Panjang. All banks certainly want the growth of both the number of customers and nominal credit. Therefore, this condition needs to get serious attention so that in the future our expectation number of customers and nominal lending of Bank BRI branch Padang Panjang will continue to increase.

One strategy that can increase the number of customers and the nominal value of Commercial Bank Commercial Retail Loans of branch Padang Panjang is by increasing the experience, satisfaction, and trust to form a customer loyalty to Commercial Retail credit facility. The concept of loyalty can be translated into various consumer activities such as repeat purchase, brand selection, commitment to a brand, and there is an emotional attachment between the consumer and the related brand. Customer loyalty as a deep commitment to buy a product or service consistently in the future (Chaudhuri \& Holbrook, 2001). Customer loyalty can be divided into two perspectives, namely purchase loyalty and attitudinal loyalty. Purchase loyalty can be interpreted as a buyback of a particular brand while attitudinal loyalty is defined as a level of commitment in terms of a unique characteristic associated to a brand (Chaudhuri \& Holbrook, 2001).

In the banking industry engaged in services that can affect customer loyalty is the brand experience (brand experience), customer satisfaction (customer satisfaction) and brand trust (brand trust). Currently Bank BRI branch Padang Panjang need to realize by understanding the brand experience then this company will be easier to develop product or service marketing strategy. According to Brakus, Schmitt, and Zarantonello (2009) brand experience is defined as the sensations, feelings, cognitions and consumer responses generated by the brand, related to the stimuli generated by brand design, brand identity, brand marketing communications, and the brand environment is marketed. Brand experience or brand experience is an important factor in influencing brand trust or brand trust. The better the brand experience established by Bank BRI, the better the brand trust in the eyes of customers.

The research hypotheses of this study are:

$\mathrm{H}_{1}$ Brand experience has a significant effect on customer satisfaction

$\mathrm{H}_{2}$ Brand experience positively influence the brand trust

$\mathrm{H}_{3}$ Customer satisfaction has a positive effect on brand trust

$\mathrm{H}_{4}$ Brand trust has a positive effect on customer loyalty

$\mathrm{H}_{5}$ Brand experience positively affect customer loyalty

$\mathrm{H}_{6}$ Customer satisfaction has a positive effect affect customer loyalty

\section{Methods}

Population in this study is the total number of customers who are using the commercial retail credit facility of Bank BRI branch Padang Panjang. The total population is 282 customers sourced from the report PT Bank Rakyat Indonesia (Persero) Tbk branch Office Padang Panjang, (2016). The number of samples sought by using Slovin formula where the sample size obtained is 166 customers BRI branch Padang Panjang. The first data processing stage was testing instrument CFA model and 
classical assumptions (Patrisia \& Dastgir, 2017). The analytical method used in conducting the data test was by using the structural equation model processed by using the help of AMOS program version 24.

\section{Results and Discussion}

Based on the stages of data processing that has been done with the help of AMOS program can be made an overall model that shows the relationship between one variable with other variables in this study seen in Figure 1 below:

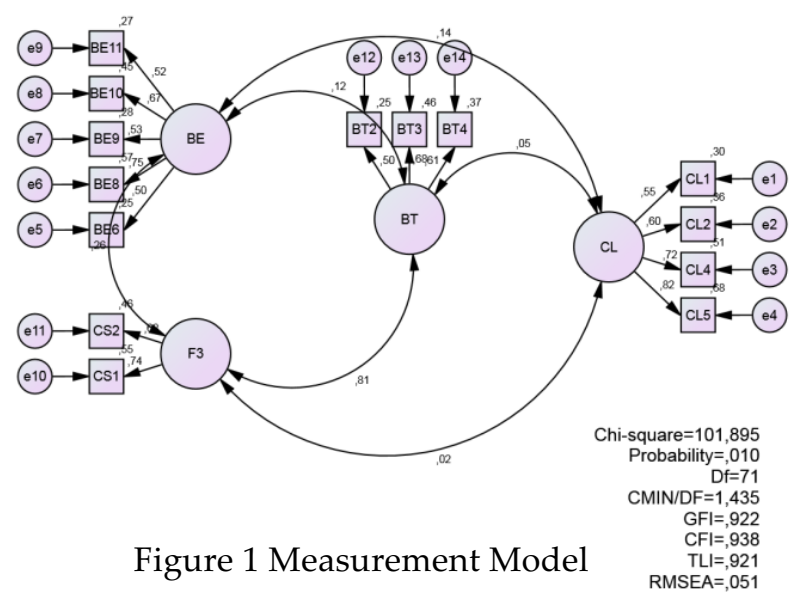

The results of data analysis are shown in the Table 2 below.

Table 2 Goodness of Fit Measurement Model

\begin{tabular}{lccc}
\hline $\begin{array}{c}\text { Goodness of } \\
\text { Fit Measure }\end{array}$ & $\begin{array}{c}\text { Coefficient } \\
\text { Value }\end{array}$ & $\begin{array}{c}\text { Cut } \\
\text { off }\end{array}$ & Conclusions \\
\hline Chi Square & 101.895 & 14.341 & Better Fit \\
\hline Probability (p) & 0.10 & $\geq 0,05$ & Better Fit \\
\hline RMSEA & 0.051 & $\leq 0,08$ & Better Fit \\
\hline GFI & 0.922 & $\geq 0.90$ & Better Fit \\
\hline CMIN/DF & 1.435 & $\leq 2,00$ & Better Fit \\
\hline TLI & 0.921 & $\geq 0,90$ & Better Fit \\
\hline CFI & 0.938 & $\geq 0,90$ & Better Fit \\
\hline
\end{tabular}

The test result showed that the value of chi-square calculated obtained is 101.895 is above the chisquare table of 14.341. In testing the model specification obtained probability value of 0.10 . The resulting probability value is above 0.05 . At the testing stage of model specification also seen that the value of RMSEA produced is equal to $0,051<0,008$. GFI value obtained $0.922>0.90$, in the data processing stage also obtained the value of CMIN / DF of $1.435<2$, TLI value obtained is $0.921>0.90$ while the value of CFI of $0.938>0.90$ so it can be concluded that all the requirements required in conducting SEM analysis have been met so that further processing stages can be implemented immediately (Wardi, Abror \& Trinanda, 2018)

\section{Structural Model}

The results of structural image model can be seen in Figure 2 below. The model shows that there is influence between brand experience to customer satisfaction with negative sign of 0,02 , while the influence formed between customer satisfaction to brand trust is 0,10 . In the model also seen the influence formed between brand experience to brand trust is 0.11 . In structural framework model seen that brand experience have influence to customer loyalty equal to 0.05 , in structural model also like that brand trust have influence to customer loyalty equal to 0,34 . Given the direct relationship 
that exists in each exogenous and endogenous variable, direct and indirect impact testing can be performed.

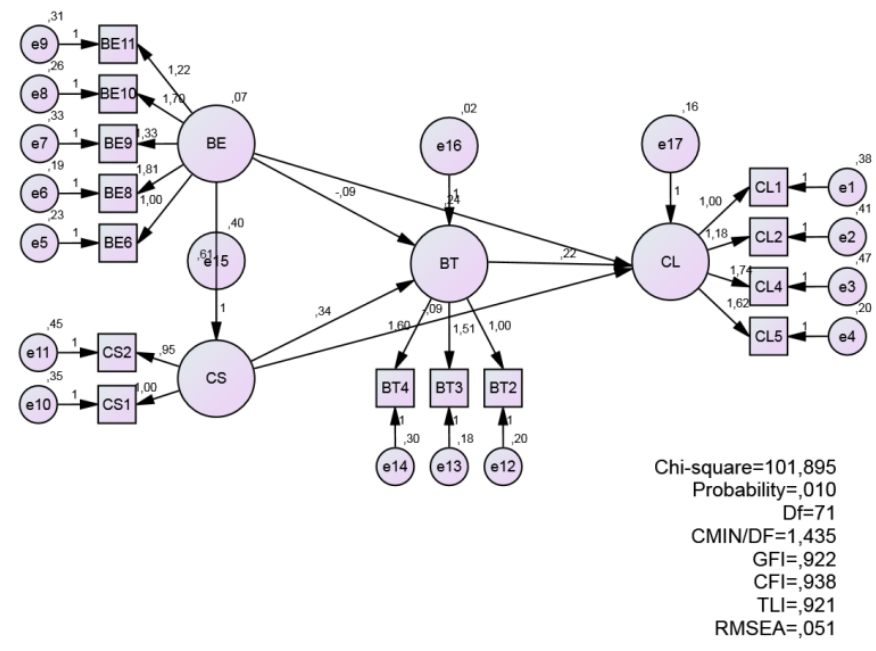

Figure 2 Structural Model

\section{Hypotheses testing}

The direct effect test aims to examine the magnitude of direct influence formed between exogenous variables to endogenous variable. The results are presented in Table 3.

Table 3 Results of hypotheses testing

\begin{tabular}{|c|c|c|c|c|}
\hline Information & Estimate & Prob. & $\begin{array}{l}\text { Cut } \\
\text { Off }\end{array}$ & Conclusions \\
\hline $\mathrm{Cs} \leftarrow \quad \mathrm{Be}$ & 0.022 & 0.646 & 0.05 & Not Significant \\
\hline $\mathrm{Bt} \leftarrow-\mathrm{Be}$ & 0.112 & 0.011 & 0.05 & Significant \\
\hline $\mathrm{Bt} \leftarrow$ Cs & 0.121 & 0.080 & ${ }^{*} 0.10^{*}$ & Significant \\
\hline $\mathrm{C} \leftarrow \mathrm{Bt}$ & 0.137 & 0.021 & 0.05 & Significant \\
\hline $\mathrm{C} \leftarrow \mathrm{Be}$ & 0.209 & 0.000 & 0.05 & Significant \\
\hline $\mathrm{C} \leftarrow$ Cs & 4.775 & 0.335 & 0.05 & Not Significant \\
\hline
\end{tabular}

Based on the results of statistical tests that have been done, the variable brand experiment (Be) has a regression coefficient of 1.946 , which is reinforced with a probability value of 0.646 . The data processing is done by using the error rate of 0.05 . Results obtained show that the probability value generated 0.646 is above the error rate of 0.05 . Thus, the decision is Ho rejected and Ha accepted so it can be concluded that the brand experience does not significantly affect customer satisfaction in using the services of Bank Rakyat Indonesia (Persero) Tbk branch Padang Panjang.

The results of hypothesis testing that aims to prove the direct influence between brand experience (Be) on brand trust $(\mathrm{Bt})$ obtained by the value of regression coefficient (estimate) of 0.112 . The results obtained are reinforced with a probability value of 0.011 . The data processing is done by using the error rate of 0.05 . The results obtained show that the probability value of $0.011<$ alpha 0.05 then the decision is Ho rejected and Ha accepted so that it can be concluded that the brand experience significantly influence brand trust in using the services of Bank Rakyat Indonesia (Persero) Tbk branch Padang Panjang.

In accordance with the results of hypothesis testing that aims to prove the influence of customer satisfaction on brand trust (Bt) obtained estimate value of 0.121 which is evidenced by a probability value of 0.080 . The data processing is done by using error rate of 0.10 . The result obtained shows that the probability value of 0.080 is still below the error level of 0.10 so that the decision is Ho is rejected and $\mathrm{Ha}$ is accepted so it can be concluded that customer satisfaction significantly affects the brand trust felt by the customer in using Bank Rakyat Indonesia (Persero) Tbk services. 
At the stage of statistical testing also known that brand trust variables have positive signified regression coefficient of 0.137 with probability value 0.021 . The process of statistical testing is done using an error rate of 0.05 . The result obtained shows that the probability value of 0.021 is below the error rate of 0.05 then the decision is Ho is rejected and Ha accepted so it can be concluded that brand trust has significant effect on customer loyalty in using Bank Rakyat Indonesia (Persero) Tbk branch Padang Panjang.

At the stage of testing the fourth hypothesis that aims to determine the direct influence formed between brand experience to customer loyalty. From the stages of processing obtained estimate coefficient value of 0209 . The obtained coefficient value is amplified with probability of 0.000 . The data processing is done by using the error rate of 0.05 . The results obtained show that the probability value of 0.000 is below 0.05 . then the decision is Ho is rejected and Ha accepted so it can be concluded that the brand experience affects customer loyalty in using the services of Bank Rakyat Indonesia (Persero) Tbk branch Padang Panjang.

In accordance with the stages of testing the direct influence between customer satisfaction with customer loyalty obtained by the value of regression coefficient of 4775 . The obtained coefficient value is reinforced with probability value of 0.335 . Stages of data processing is done by using the error rate of 0.05 . Thus, the probability value obtained is above the error rate of 0.05 . Then the decision is Ho accepted and Ha rejected so that it can be concluded that customer satisfaction has no significant effect on customer loyalty in using the services of Bank Rakyat Indonesia (Persero) Tbk branch Padang Panjang.

Moreover, indirect test is intended to determine the magnitude of the effect formed due to the combination of exogenous variables to endogenous variables mediated by the moderator. Based on the results of data processing that has been obtained summary of the results seen in Table 4 .

Table 4 Results of indirect effect test

\begin{tabular}{ccccc}
\hline Variable & $\mathrm{Be}$ & $\mathrm{Cs}$ & $\mathrm{Bt}$ & $\mathrm{C}$ \\
\hline $\mathrm{Cs}$ & 0.000 & 0.000 & 0.000 & 0.000 \\
\hline $\mathrm{Bt}$ & -0.003 & 0.000 & 0.000 & 0.000 \\
\hline $\mathrm{C}$ & 0.038 & 0.041 & 0.000 & 0.000 \\
\hline
\end{tabular}

Based on the results of testing the effect is not directly seen that the influence of brand experience on customer loyalty through brand trust is 0,000 , thus it can be concluded that the brand experience does not guarantee the satisfaction felt by consumers after re-use the same product or service brand that does not encourage the formation of trust in the brand services used.

From model equation seen that brand experience to brand trust through customer satisfaction produce coefficient marked negative that is 0,003 . The results obtained show experience in using the brand will encourage confidence in the brand will be able to reduce the value of satisfaction in using the service brand. The situation is contrary to the theory. This happens because customers generally borrow in a state of urgency and need a short time in the liquid so that they are forced to become commercial retail products BRI as the main choice.

In accordance with the results of tests that have been done show that customer satisfaction (CS) has an influence on customer loyalty (C) after through brand trust, with the coefficient obtained is 0.041 so it is seen that when satisfaction perceived customers continue menigkat, will encourage the formation of trust, so that the combination of satisfaction and trust will encourage the emergence of loyalty. However, such indirect effects cannot be proven because the direct influence of customer satisfaction on customer loyalty cannot be proven.

At the stage of testing indirect influence is known that brand experience affects customer loyalty after through brand trust with coefficient of indirect effect of 0.038 . Thus, it can be concluded that the 
experience of using bank products will encourage confidence so as to increase customer loyalty in using the same bank services.

Based on the results obtained can be made model of structural framework that shows the direct influence and not all research variables used in this research model that is look at Table 5 below:

Table 5 Results of total effect test

\begin{tabular}{ccccc}
\hline \multirow{2}{*}{ Variable } & \multirow{2}{*}{ Be } & Cs & Bt & C \\
\hline $\mathrm{Cs}$ & 0.022 & 0.000 & 0.000 & 0.000 \\
\hline $\mathrm{Bt}$ & 0.110 & 0.121 & 0.000 & 0.000 \\
\hline $\mathrm{C}$ & 0.247 & -0.010 & 0.137 & 0.000 \\
\hline
\end{tabular}

In the total effect table shows that the total influence formed between brand experience on brand trust is 0.022 or $2.22 \%$. Total influence is only a direct influence. In addition, the influence of brand experience on brand trust is 0.110 or $11 \%$ lower than the direct influence formed between customer satisfaction against brand trust of 0.121 or $12.10 \%$, if observed from the test results the direct influence is higher than indirect influence.

In total effect test also seen total direct and indirect influence between brand experience to customer loyalty through brand trust reaches 0.247 or $24,70 \%$. The findings occur because of the sum of total direct influence of 0209 or $(20.90 \%)$ with total indirect influence of 0.038 or $(3.80 \%)$. The results obtained imply a greater direct effect of indirect influence.

The lowest total influence occurs in testing the influence of customer satisfaction on customer loyalty through brand trust, the coefficient that is formed is negative ie -0.010 . In the test also found total influence formed between brand trust with customer loyalty equal to 0,137 or $13,70 \%$. Thus, it can be concluded that the highest total influence is when testing between and experience of customer loyalty through brand trusts perceived by customers in using commercial mortgage products Bank Rakyat Indonesia branch Padang Panjang.

\section{The Influence of Brand Experience on Customer Satisfaction}

Based on the results of hypothesis testing found that brand experience does not affect customer satisfaction perceived customers in using commercial credit products Bank Rakyat Indonesia (Persero) Tbk branch Padang. The results of this study are in line with the results of Aeker (1997) which revealed that the experience in brand use has a positive effect on customer satisfaction. Keller's (2014) same theory expressed that the experience formed in the consumer is a guarantee the creation of a sense of satisfaction in them we consume a product brand.

However, the findings are not in line with the results of Chou and Huang (2017) found that brand experience positively affect brand satisfaction. Veloutsou (2015) shows that brand experience showed the experience that consumers have in using a product brand. The experience that consumers have in using a brand is formed because of the convenience and satisfaction in using the brand. Hadi (2015) found that brand experience had a positive effect on customer satisfaction, the results obtained showed a high experience in using a product brand seen from repeated activities in using the same product brand, the routine perceived by consumers in using brand is a satisfaction guarantee perceived by consumers in using a product brand within a certain period. The results of Lishan et al. (2017) revealed that satisfaction indicates a match between consumers perceived expectations between consumers perceived performance when using the product brand

\section{The Influence of Brand Experience on Brand trust}

Based on the results above, it found that brand experience has significant effect on brand trust perceived customer commercial retail credit Bank Rakyat Indonesia (Persero) Tbk Branch Padang Panjang. The findings obtained are consistent with Keller's (2014) opinion which suggests that experience in brand use will encourage stronger confidence in the use of a brand. 
The findings obtained are consistent with the results of research conducted by Khan Imran and Zillur Rahman. (2016) found that brand experience has a positive effect on brand trust. Hadi (2015) found that brand experience has a positive effect on brand trust. The results obtained indicate that the higher experience in work will encourage increased brand trust. Kusuma (2014) concluded that Brand experience has a significant influence on brand trust in Harley Davidson brand. Chao-Chin Huang (2015) reveals that brand experience or brand experience shows past actions in using a brand.

\section{The Influence of Brand Trust on Customer Satisfaction}

Based on the analysis above showed that brand trust has a positive and significant impact on customer satisfaction that is felt in using commercial credit commercial of Rakyat Indonesia (Persero) Tbk branch Padang Panjang. The results obtained are consistent with the theory described by Durianto et al (2009) which states that brand trust can encourage consumer satisfaction. The higher the level of trust they feel is a guarantee of satisfaction that they will feel when the same product is reused.

The findings obtained at the third hypothesis testing stage consistent with the results of the research by Widyanti (2015) found that brand trust has a positive effect on customer satisfaction. Consistent results are also obtained by William et al (2017) who found that high brand trust will encourage increased customer satisfaction. The same results were also obtained in Herlambang's (2016) study which found that brand trusts positively affect customer satisfaction felt by customers in using the services of a bank.

\section{The Influence of Brand Trust on Customer Loyalty}

In accordance with the test results found that brand trust affects customer satisfaction in using commercial credit products Bank Rakyat Indonesia (Persero) Tbk branch Padang Panjang. The findings obtained are consistent with the theory described by Durianto et al. (2009) which states that one of the factors that shape customer commitment in using a brand is brand trust. The higher the consumer's perceived confidence in the brand will encourage their loyalty to strengthen. The findings obtained at the stage of hypothesis testing in line with Park's research results, Eunil et al. (2017) in his research indicate the role of trust mediation in promoting loyalty, these findings suggest that these confidence variables are a significant determinant of consumer loyalty. Ercis et al. (2012) concluded there is a positive relationship between brand trust with customer loyalty. In that study found an influence between brand trust towards the creation of customer loyalty.

\section{The Influence of Brand Experience on Customer Loyalty}

Based on the results of hypothesis testing also found that the brand experience has a positive and significant impact on customer loyalty in using commercial credit commercial of Rakyat Indonesia (Persero) Tbk branch Padang Panjang. Brand Experience in using the brand can form the formation of consumer commitment to continue to use the same product brand (Aeker, 1997). Positive experiences of using that are consistently perceived by consumers form a stronger loyalty in the consumers of a brand. The results obtained in line with research conducted by Brakus et al. (2009) found that brand experience affects customer loyalty either directly or indirectly. Researchers differentiate some dimensions of experience and build a brand experience scale that includes four dimensions: sensory, affective, intellectual, and behavioral. Kusuma (2014) concluded that brand experience has a significant influence on customer loyalty on Harley Davidson brand.

\section{Influence of Customer Satisfaction to Customer Loyalty}

Based on the results of hypothesis testing that has been done can be concluded that customer satisfaction has no significant effect on customer loyalty in using commercial credit services Bank Rakyat Indonesia (Persero) Tbk branch Padang Panjang. The findings obtained are not consistent with the results of research conducted by Nurkholis (2004) states that customer satisfaction is closely related to customer loyalty, where satisfied customers will become loyal customers. Then the loyal 
customer will become a powerful marketing force for the company by providing recommendations and positive information to other prospective customers. Omid Kamran et al (2017) states that customer satisfaction is positively associated with customer loyalty. The study was conducted by conducting a survey on 505 buyers at supermarkets and hypermarkets in Spain.

\section{Conclusions}

Based on the analysis of hypothesis testing results that have been done then put forward some important conclusions are:

1. Brand experience has no significant effect on customer satisfaction in using Bank Rakyat Indonesia (Persero) Tbk branch Padang Panjang.

2. Brand experience positively influence the brand trust in using Bank Rakyat Indonesia (Persero) Tbk branch Padang Panjang.

3. Customer satisfaction has a positive effect on brand trust in using Bank Rakyat Indonesia (Persero) Tbk branch Padang Panjang.

4. Brand trust has a positive effect on customer loyalty in using Bank Rakyat Indonesia (Persero) Tbk branch Padang Panjang.

5. Brand experience positively affect customer loyalty in using Bank Rakyat Indonesia (Persero) Tbk branch Padang Panjang.

6. Customer satisfaction does not affect customer loyalty in using Bank Rakyat Indonesia (Persero) Tbk branch Padang Panjang.

Based on the results of data analysis and discussion, it can be taken as follows:

1. Future researchers are advised to increase the number of sample sizes to be used, the increasing number of sample sizes used will increase the accuracy and accuracy of the research results obtained.

2. Researchers in the future are advised to be more selective in choosing respondent such suggestions to reduce data confusion so as to encourage the increased accuracy and accuracy of research results to be obtained.

3. Future researchers are advised to add a number of new variables that can also affect job engagement, the suggestion is important to encourage improving the accuracy and accuracy of research results obtained in the future.

\section{References}

Badawi. (2007). Pengaruh trust in brand dan satisfaction terhadap keterikatan merek (Studi pada merek perbankan syariah di cirebon). Buletin Ekonomi, 5.

Baron, R. M., \& Kenny, D. A. (1986). The moderator-mediator variable distinction in social psychological research: Conceptual, strategic, and statistical considerations. Journal of Personality and Social Psychology, 51, 1173-1182

Durianto, Darmadi, Sugiarto, \& Lie, Joko Budiman. (2004). Brand Equality Ten, Strategi Memimpin Pasar. Jakarta: Gramedia PustakaUtama.

Fatmayanti, Susy Raih Nur. (2012). Analisis iklan dan endoser terhadap pembentukan brand awareness serta dampaknya pada keputusan pembelian produk Kecap Manis ABC. Skripsi. Universitas Diponegoro, Semarang.

Habibi, Mohammad Reza, Michel, Laroche \& Marie, Odile Richard. (2015). The roles of brand community and community engagement in building brand trust on social media. Journal Computer and Human Behavior, 37, 152 - 161.

Indrianto, Nur \& Bambang Supomo. (199)9. Metodologi Penelitian Bisnis. Yogyakarta: BPFE Yogyakarta.

Merriless, Bil. (2016). Interactive brand experience pathways to customer brand engagement and value co-reaction. Journal of Product \& Brand Management, 25(5), 402-408. doi: 10.1108/JPBM04-2016-1151

Mowen, Jhon \& Michel Minor. (2002). Perilaku Konsumen. Lina Salim (Translator). Jakarta: Erlangga. 
Keller, Lane Kevin. (2008). Strategic Brand Management. McGraw-Hill, Irwin.

Khan, Imran Sillur Rahman Mobin Fatma. (2016). The role of customer brand engagement and brand experience in online banking. International Journal of Banking Marketing, 34(7).

Kotler, Philip. (2009). Manajemen Pemasaran. Edisi Melenium. Jakarta: Prenhallindo

Kusuma, Surya Yohanes. (2014). Pengaruh brand experience terhadap brand engagement melalui brand satisfaction dan brand trust harley davidson di Surabaya. Jurnal Manajemen Pemasaran Petra, 2(1).

Loureiro, Coreiro Mania Sandra, Tatjana Gorgus, \& Hans Reudiger Kaufmann. (2017). Antecedent and outcomes of online brand engagement the role of brand love on enhancing electronic word of mouth. International Journal of Banking Marketing, 34(7).

Lovelock. (2013). Marketing Stategic. Third Edition. McGraw-Hill, Irwin.

Nyohardi, Paramita. (2016). Pengaruh brand experience terhadap brand engagement melalui brand satisfaction dan brand attitude. Jurnal Bisnis dan Manajemen, 52 (11).

Patrisia, D., \& Dastgir, S. (2017). Diversification and corporate social performance in manufacturing companies. Eurasian Business Review, 7(1), 121-139. doi: 10.1007/s40821-016-0052-6

Rini, Ayu Sitia \& Sulistyawati. (2016). Pengaruh brand trust, customer satisfaction dan coperate social responsibility terhadap brand engagement. Jurnal Manajemen Pemasaran, 5(2). Univeristas Udayana, Bali.

Rismiati, E. Catur. (2006). Management Periklanan. Penerbit BPFE, Yogyakarta.

Sibagariang, Sem Christiana \& Nursanti, Tanjung Desy. (2010). Pengaruh brand image dan brand trust terhadap brand engagement pada PT Bank Sinarmas. Jurnal The Winners, 11(2).

Wardi, Y., Abror, A., \& Trinanda, O. (2018). Halal tourism: Antecedent of tourist's satisfaction and word of mouth (WOM). Asia Pacific Journal of Tourism Research, 23(5), 463-472. doi: $10.1080 / 10941665.2018 .1466816$ 